\title{
Explaining Level and Development of Writing Proficiency of Low-Achieving Adolescents by Different Types of Engagement
}

\author{
Ilona de Milliano ${ }^{1}$, Amos van Gelderen ${ }^{2,3}$, Peter Sleegers ${ }^{4}$ \\ ${ }^{1}$ Department Educational and Pedagogical Sciences, University of Amsterdam, Amsterdam, The Netherlands \\ ${ }^{2}$ Kohnstamm Institute, University of Amsterdam, Amsterdam, The Netherlands \\ ${ }^{3}$ Rotterdam University of Applied Sciences, Rotterdam, The Netherlands \\ ${ }^{4}$ Department of Educational Organization and Management, University of Twente, Enschede, The Netherlands \\ Email: i.i.c.m.de.milliano@hva.nl, avangelderen@kohnstamm.uva.nl, petersleegers@bmc.nl
}

How to cite this paper: de Milliano, I., van Gelderen, A., \& Sleegers, P. (2017). Explaining Level and Development of Writing Proficiency of Low-Achieving Adolescents by Different Types of Engagement. Creative Education, 8, 693-715.

https://doi.org/10.4236/ce.2017.85054

Received: February 13, 2017

Accepted: April 27, 2017

Published: April 30, 2017

Copyright $\odot 2017$ by authors and Scientific Research Publishing Inc. This work is licensed under the Creative Commons Attribution International License (CC BY 4.0).

http://creativecommons.org/licenses/by/4.0/

\begin{abstract}
This longitudinal study explored the degree in which level and development of writing proficiency of a group of 63 low-achieving adolescents can be explained by their engagement in literacy activities. These adolescents were intensively followed from grades 7 to 9 , measuring their writing proficiency and their engagement each year focusing on affective, cognitive and behavioral aspects of engagement. Results indicate that level of writing proficiency increases from year to year, but that this development cannot be predicted by any of the engagement measures. In contrast, the level of writing proficiency of the students can be explained by aspects of affective and behavioral engagement. Therefore, the results underline the importance of distinguishing between the level and development of writing proficiency in examining relationships between engagement and writing achievement of low-achieving adolescents. Although average level of students' writing proficiency is explained by affective and behavioral engagement, these aspects of engagement do not explain growth in writing proficiency in the course of the three grades studied. Implications of these findings for future research and for educational practice are discussed.
\end{abstract}

\section{Keywords}

Writing Proficiency, Engagement, Low-Achieving Students, Motivation, Self-Regulation, Classroom Observations, Secondary Education

\section{Introduction}

Learning to write begins at school entry and develops through formal schooling 
years and beyond. During their school careers, students are increasingly asked to demonstrate their knowledge through writing (Graham \& Perin, 2007). Yet, several studies signal that many adolescents have difficulty composing text at a level required by the school curriculum but also from the perspectives of their future career and societal requirements (Alliance for Excellent Education, 2006; Baumert et al., 2001; Inspectie van het Onderwijs, 2008; Hofman, Spijkerboer, \& Timmermans, 2009; OECD, 2000; Salahu-Din, Persky, \& Miller, 2008). As writing becomes increasingly demanding through the grades, active engagement of adolescents in literacy activities may be an important determinant of writing development (Boscolo, 2012; Bruning \& Horn, 2000). Engagement is defined as students' feelings, thoughts and behaviors concerning a more or less specified object, such as school, learning, reading or writing (Appleton, Christenson, \& Furlong, 2008; Fredricks, Blumenfeld, \& Paris, 2004; Guthrie, Wigfield, \& You, 2012; Linnenbrink \& Pintrich, 2003).

Most existing research on the relationship between writing proficiency and engagement targets heterogeneous groups including high- and low-achieving students (Klassen, 2002; Pajares, 2003). In such populations, patterns existing in the low achieving groups may be obscured by the large differences between students. In addition, studies hitherto analyzed the relationship between writing proficiency and engagement at one point in time or in cross-sectional designs (Klassen, 2002; Pajares, 2003). These designs provide insights in the degree to which the level of writing proficiency can be explained by students' positive engagement in literacy activities, but do not give insight in the degree that development of writing during a certain period can be explained by literacy engagement. Therefore, longitudinal research is necessary (Klassen, 2002; Pajares, 2003). This type of study may inform a theory about the nature of the relationship between writing proficiency and engagement. Are more engaged students simply better in writing, or can their engagement be linked to their writing proficiency development during a certain period of schooling (i.e. do differences in engagement also explain differences in writing development during that period)?

This study therefore addresses two gaps in the literature. First, it aims at low-achieving students as a group, since this group deserves special attention given their difficulty attaining minimal standards of writing proficiency. Second, it aims at exploring engagement as a predictor of both level and development of writing proficiency. Therefore, we used a longitudinal design and observed a focused sample of low-achieving adolescents from grades 7 to 9. In addition, multiple indicators of engagement were used to examine students' cognitive effort, affective reactions and actual behavior towards literacy activities within their classrooms.

\subsection{Engagement}

Contemporary definitions of engagement emphasize that engagement is a multidimensional construct, including affective engagement, cognitive engagement and behavioral engagement (Appleton et al., 2008; Fredricks et al., 2004; Guthrie 
et al., 2012; Linnenbrink \& Pintrich, 2003). Since researchers in the field of writing focused on the cognitive processes for a fairly long time, we start by outlining this facet of engagement. Next, we will provide more detailed definitions of what is understoodas affective and behavioral engagement.

\subsubsection{Cognitive Engagement}

Cognitive engagement refers to students' willingness to exert mental effort needed to perform challenging academic tasks as well as to use self-regulatory strategies to guide one's cognitive efforts. The application of strategies is also referred to as cognitive self-regulation (Torrance, Fidalgo, \& Garcia, 2007; Zimmerman \& Risemberg, 1997). A great deal of research has been done regarding cognitive self-regulation and its relation with texts produced by writers of diverging proficiency (Graham, 2006; Van Gelderen, 1997). Findings, in general, suggest that better writers are more strategic than poorer writers. In addition, it was found that, even among low achieving adolescents, those who plan and revise their writing more intensively and who check their formulation more precisely write texts of better quality (De Milliano, Van Gelderen, \& Sleegers, 2012). The writing of low-achieving adolescents can be characterized to a great extent by the model of "knowledge telling" (Bereiter \& Scardamalia, 1987). Knowledge telling involves retrieving content relevant to the topic from long-term memory and writing it down without much planning or reviewing (Harris, Graham, Brindle, \& Sandmel, 2009). Using cognitive strategies requires the expenditure of mental effort. For low-achieving students this may be relatively difficult, given their arrears in knowledge about topics for writing and about language (vocabulary and grammar) (Englert et al., 1988; Kellogg, 1987; McCutchen, 1986; Olinghouse \& Graham, 2009). On the other hand, cognitive self-regulation of lowachieving adolescents can be an important determinant of their writing, as research findings indicate that developing writers gain more knowledge about writing strategies over time and that instruction directed at cognitive self-regulation enhances writing skills, especially of low-achieving students (De La Paz, Swanson, \& Graham, 1998; Englert, 1992; Graham \& Perin, 2007; Harris et al., 2009). Based on these findings, we may assume that low-achieving adolescents who put more cognitive effort in literacy activities such as writing and reading and use more self-regulative activities do not only have a higher level of writing proficiency but also obtain more progression in writing proficiency over time. However, there is no direct evidence from longitudinal studies, yet, supporting that last assumption.

\subsubsection{Affective Engagement}

Affective engagement refers to motivational factors, including students' emotional reactions to a task, their beliefs about their ability to perform a task and their beliefs about the importance of the task. Recent models of the writing process acknowledge the importance of affective variables (Hayes, 1996; Zimmerman \& Risemberg, 1997). Affective engagement refers to motivational proce- 
sses during writing. Motivation is defined as the beliefs, values and goals individuals have for domain specific activities (Eccles \& Wigfield, 2002). It is assumed that students' beliefs about their ability to perform a task (self-efficacy) and their subjective values about the importance of the task (subjective task values) influence students' effort, persistence and task achievement (Wigfield \& Eccles, 2000), especially when activities are cognitively demanding. Writing is regarded as an extremely demanding activity, because, typically, many different cognitive activities have to be performed to bring writing tasks to a successful end (Bereiter \& Scardamalia, 1987; Bruning \& Horn, 2000; Graham, 2006; Graham, Berninger, \& Fan, 2007; Hayes \& Flower, 1980; Hidi \& Boscolo, 2006; Klassen, 2002; Pajares, 2003; Schunk \& Zimmerman, 1994; Van Gelderen, 1997). Accordingly, motivation for writing may not only be related to a higher level of writing proficiency, but may also explain differences in writing development over time. Students who are motivated for writing tend to put more effort in learning to increase their writing skills. In examining the role of students' affective engagement in level and development of writing proficiency, we focus on two of the most important motivational factors in the field of writing: self-efficacy and subjective task values.

Self-efficacy for writing is a persons' belief in the ability to successfully complete writing tasks (cf. Bandura, 1997), whereas subjective task values is a complex composite comprising attainment values, intrinsic values, utility values and costs (Eccles, 2005). Research into the role of self-efficacy (Klassen, 2002; Pajares, 2003; Pajares \& Valiante, 2006), shows that self-efficacy beliefs play an important role in predicting writing achievement. Research into subjective task values has mainly focused on interest in the topics for writing rather than on writing as an appealing activity in itself (Hidi \& Boscolo, 2006). However, some research explored the idea of writing as interesting activity in itself. The available evidence suggests that students' positive values for writing as activity is related to their writing achievements (Boscolo, 2012; Graham et al., 2007; Lipstein \& Renninger, 2007). Although findings of different studies suggest that self-efficacy and subjective task values predict students' level of writing proficiency, less is known about the relationship between affective engagement and the development of writing proficiency over time.

\subsubsection{Behavioral Engagement}

Behavioral engagement refers to students' participation in learning opportunities and tasks as offered by teachers, including attending to and completing literacy tasks, following rules and instruction, and exercising self-control (Ponitz, Rimm-Kaufman, Grim, \& Curby, 2009). Behavioral engagement in academic activities is viewed as an important predictor of academic achievement as students' participation in academic activities is a prerequisite for learning (Fredricks et al., 2004; Greenwood, Horton, \& Utley, 2002; Pressley et al., 2001). For writing, we found no research directed at the relationship between behavioral engagement in the classroom and writing achievement. In the field of reading, however, studies 
conducted in kindergarten and elementary schools have shown that behavioral engagement in the classroom is positively related to reading achievement (Berliner, 1979; Dolezal, Welsh, Pressley, \& Vincent, 2003; Guthrie et al., 2012; Hughes \& Kwok, 2007; Ponitz, McClelland, Matthews, \& Morrison, 2009). In their longitudinal study, Ladd and Dinella (2009) examined the effect of behavioral engagement of students (5 to 13 years old) on a variety of reading achievement tests. The findings showed that, while statistically controlling for reading achievement in grade 1 , the reading development of more engaged students improved more than for less engaged students. This is an indication that behavioral engagement in reading is not only related to students' level of reading proficiency, but also explains differences in development of reading proficiency over time. It is therefore of interest to investigate whether analogous findings apply for the relation between students' behavioral engagement and their writing proficiency.

Given the fact that behavioral engagement is responsive to variation in learning contexts and the learning opportunities and tasks offered by teachers in classrooms (Finn \& Rock, 1997), it is necessary to account for the contexts in which literacy activities are enacted in the classroom. Writing and reading activities at school are not limited to the language arts, but are enacted across varying disciplines involving different purposes, forms and processes (Applebee \& Langer, 2006; Kiuhara, Graham, \& Hawken, 2009). In the language arts, literacy practice is intended for improving proficiency in literacy tasks, whereas in content area education, literacy is used as a tool for acquiring or describing content knowledge (Graham \& Perin, 2007). In this study, we therefore, focus on two different types of subject domains of education: language arts and social studies.

\subsection{The Present Study}

The present study aimed at exploring the relationships between level and development of writing proficiency of low-achieving adolescents on one hand and the mentioned types of engagement in literacy (cognitive, affective and behavioral). In doing so, we intend to add insight to the existing literature in three important ways. First, we extend the knowledge on writing proficiency and engagement to the specific population of low-achieving adolescents, giving insight into the question whether within this group of students differences in proficiency can be explained by their engagement in literacy practice. This issue is not only of scientific importance, but also of relevance for educational policies directed specifically at the development of low-achieving students' literacy skills. Second, we will provide more insight in the explanatory role of writing engagement for development of low-achieving students' writing proficiency during a considerable stretch of time of their schooling (grades 7-9). This longitudinal approach is of interest, because it informs about possible beneficial effects of attention paid to improving writing engagement of low-achieving students in this specific period of their writing development. Third, our study will give a more comprehensive view of the role of different types of engagement for writing proficiency (both 
level and development) than is provided by the existing literature, given the fact that we study cognitive, affective and behavioral aspects of engagement at the same time. Especially the addition of actual behavioral measurements for engagement (instead of self-reports, which is the more usual approach) is a valuable aspect of this study. Actual behavior as an indication of engagement is rarely taken into account in other studies, because behavioral measurements, especially in a longitudinal design, are quite time consuming and costly. The following research questions were addressed:

1) Are affective engagement, cognitive engagement and behavioral engagement positively related to writing proficiency of low-achieving adolescents?

2) Is there significant growth in low achieving adolescents' writing proficiency from grades 7 to 9 ?

3) Do affective, behavioral and cognitive aspects of engagement explain differences in development of low achieving adolescents' writing proficiency from grades 7 to 9 ?

\section{Method}

\subsection{Participants}

Low-achieving adolescentsin this study were Dutch students in the lowest 30-percentile of general academic skills as measured by an academic aptitude test (language, reading and mathematics) taken prior to admission of secondary education (grade 7). In the Netherlands, these students are enrolled in the two lowest tracks of prevocational secondary education ${ }^{1}$. The sample in grade 7 involved 63 students ( 36 boys and 27 girls) recruited out of 10 classes from 9 ethnically mixed schools in the lowest tracks of secondary prevocational education. From each class 6 to 7 students were selected, making sure that for each class students with native and non-native backgrounds were equally represented.

In grade 7, the students were between 12 and 14 years old $(M=14.7)$. Of the sample in grade 7, 32 students were native speakers of Dutch; the other $31 \mathrm{stu}$ dents were non-native speakers of Dutch from various ethno-linguistic backgrounds (most of them from Moroccan or Turkish origin). Students diagnosed with a learning or behavioral disorder (e.g. dyslexia, ADHD), were excluded from our sample in order to ascertain that differences in writing achievement were not related to specific learning or behavioral disorders.

\subsection{Measures}

\subsubsection{Writing Proficiency}

The writing proficiency test consisted of three writing assignments in which students were asked to write a text. Each assignment specified a realistic communicative task connected to young people's daily lives. The selection of as-

${ }^{1}$ Regular secondary education in the Netherlands is divided into three tracks: prevocational secondary education (VMBO), senior general secondary education (HAVO), and pre-university education (VWO). Prevocational education is further divided into four tracks: the basic vocational program, the middle-management vocational program, the combined program, and the theoretical program (Ministry of Education, Culture and Science, 2006). 
signments was based upon a pretest among a group of students from the same population, containing more diverse writing assignments. Students commented on these assignments and the assignments that were received most positively were selected for the final test. The three assignments covered a range of text types (instructive, argumentative and narrative). In Assignment 1 (instructive), students were asked to write a letter to two students from Belgium who were going to visit the Netherlands as part of an exchange program. Their task was to provide instructions on where to meet, what to bring, etcetera. In Assignment 2 (argumentative), students were asked to imagine they were taking part in a competition for which they were saving coupons on candy bar wrappers in order to receive two free cinema tickets. However, they were unable to find wrappers with coupons, even though the deadline for the competition had not passed. The assignment was to write a letter to the firm, arguing that it was not their fault that they were not able to send the required number of coupons and convincing the recipient to send them the cinema tickets. In Assignment 3 (narrative), students were asked to write a short sequel to a story they had read, with a given start and closing sentence.

Each assignment was rated by two independent raters using a primary trait scoring procedure (Lloyd-Jones, 1977). For each assignment, the central communicative objective-or primary trait was formulated. On the basis of this primary trait, a set of rating criteria were specified (e.g. "letter conventions", "line of reasoning", or "consistency with original story"). The raters had to use these criteria to assign each student a single score. To arrive at this score, raters were provided with a scale of five benchmark texts. This scale was developed in a separate session in which a sample of forty texts was rated by two independent raters, following a procedure based on Blok (1986) and adopted in Schoonen et al. (2011). The five scale points represented the $10^{\text {th }}, 25^{\text {th }}, 50^{\text {th }}, 75^{\text {th }}$ and $90^{\text {th }}$ percentiles of these forty texts. The final interrater reliability of the scores was satisfactory: For Assignment $1, r=.89, .82$, and .77 in grades 7,8 and 9 respectively; for Assignment $2, r=.88, .83$ and .75 in grades 7,8 and 9 respectively; and for Assignment $3, r=.88, .86$ and .75 in grades 7,8 and 9 , respectively. Across all three years, one rater remained the same in order to avoid differences in severity of rating and to make the ratings comparable over years. Writing proficiency in each grade was represented by a sum score of the scores for assignment 1,2 and 3 (grade 7 Cronbach $\alpha=.69$, grade 8 Cronbach $\alpha=.71$, grade 9 Cronbach $\alpha$ $=.52)$. Next, a sum score representing writing proficiency across grades 7 to 9 was computed. The reliability of this score was good (Cronbach $\alpha=.83$ ).

\subsubsection{Engagement}

Affective and cognitive engagement were measured using questionnaires. To assess affective engagement, an adapted version of the Attitude Scale towards English as school subject developed by the Dutch Institute of Testing (CITO) was used. For the purpose of this study, the questions were adapted to reading and writing. Half of the items concerned writing and half of the items concerned 
reading.

Three aspects of affective engagement were assessed (10 items for each aspect): 1) self-efficacy (e.g. "I am good at writing"), 2) intrinsic value (e.g. "I enjoy writing"), 3) utility value (e.g. "Writing proficiency is important to get a job"). Students were asked to indicate the extent to which the items referring to the three aspects of affective engagement applied to them on five point scales $(1=$ not all true, 5 = very true).

Two aspects of cognitive engagement were assessed: 1) perceived effort (10 items from the above mentioned attitude questionnaire; e.g. "I exert additional effort to become a better writer"), and 2) perceived self-regulative behavior in reading and writing (33 items). The strategies represent the self-regulatory activities generally distinguished in the literature: orientation, planning, monitoring, controlling, testing and evaluation. The writing items (17 items; e.g. "While I'm writing, I consider whether my audience will comprehend what I mean.") were based on cognitive models for writing (Bereiter \& Scardamalia, 1987; Hayes \& Flower, 1980; Hayes, 1996), the reading items (16 items; e.g. "While I'm reading, I check whether I still comprehend what I'm reading.") were based on previous research into metacognitive knowledge relevant for reading (Baker \& Brown, 1984; Pressley \& Afflerbach, 1995). Students were asked to indicate how often they apply a range of writing and reading strategies on a five-point scale $(1=$ seldom; 5 = very frequently).

The reliabilities of the five scales for affective and cognitive engagement were established in each grade ( 7 to 9 ). The reliabilities were found to be satisfactory in all cases $(.76<$ Cronbach's alpha $>.89)$. Next, for each of the five scales a sum score representing the scores across grades 7 to 9 was computed. The measures of affective and cognitive engagement have satisfactory reliabilities across grades (Cronbach's alpha is .78 for Self-Efficacy, .84 for Intrinsic Value, and .75 for Utility Value, .84 for Perceived Effort and.82 for Perceived Self-Regulation).

To measure students' behavioral engagement in classroom activities, real-time observations were conducted in regular lessons of Dutch language arts (DL) and lessons in social studies (SS). For each student, two lessons per subject were observed in each grade, resulting in an overall average of 12 hours of observed lessons per student ${ }^{2}$. During classroom observations, two aspects were coded every ninety seconds for every student in the sample. The first aspect coded was whether the lesson was directed at Literacy Activities (e.g. writing, metacognitive knowledge, vocabulary, grammar, spelling and punctuation). The second aspect coded was whether the target student was On-Task (e.g. working on a problem, answering a question, listening to the teacher or a classmate making an on-task contribution). Since the duration of lessons varied over schools, the total observation time differed for individual students. Therefore, we corrected the time-on-task scores for observation time by dividing the time that students spent

${ }^{2}$ Participants became distributed over an increasing number of classes from grade 7-9. Therefore, an increasing number of classroom observations was needed to observe all participants in two lessons for each subject. In some observed lessons only 1 student participated in the study. In total 200 classroom observations were conducted (40 in grade 7, 48 in grade 8 and 112 in grade 9). 
in a particular literacy activity by the total time students were observed. Next, the time that students were on task in the particular literacy activity was multiplied with this quotient ${ }^{3}$. From the 167 hours of real-time observation, 8 hours were coded simultaneously by two observers. In sum, 267 segments of 1.5 -min each were coded twice ( $5 \%$ of a total of 6.680 segments). To estimate inter-observer-reliabilities we calculated Cohen's kappa. For Literacy Activities kappa was .89 , for On-Task behavior kappa was .80 . These reliabilities are sufficient for our research purposes. Next, sum scores representing behavioral engagement in language arts and social studies across grades 7 to 9 were computed. Low correlations between grades were found, suggesting that behavioral engagement in literacy related activities of students varied considerably across lessons. Given the situated nature of behavioral engagement, this is not surprising. An approximation of students' being on task in literacy activities by averaging the scores across grades is therefore justified.

\subsection{Procedure}

The writing proficiency test was administered in the spring semester in each of the grades in two 45-min sessions. The questionnaires were administered in each of the three grades in the fall semester in one 45-min session. Finally, for each subject (DL and SS) in each grade one lesson in the fall semester and one lesson in the spring semester were observed. This means that yearly 4 lessons for each student were observed. The writing proficiency test was conducted in students' classrooms during the school day and administered by trained research assistants. The students' teacher was always present to maintain order. The questionnaires were administered by trained research assistants in separate group sessions during the school day. Students' questions were answered by the test leaders according to a standardized protocol.

\subsection{Attrition and Missing Data}

Due to attrition (e.g. illness, moving, problems at home or school), the number of participating students decreased in the course of our study. On the other hand, because of mobility of students, the number of classes and schools involved in the study increased. Ultimately in grade 9 , the sample consisted of 52 students distributed over 28 classes and 11 schools. In total, $8.7 \%$ of our complete data set was missing. EM estimation was used to estimate and impute the missing data on the dependent variable (writing proficiency). For the independent variables (indicators of engagement), we averaged the scores that were obtained through the grades. As a check, all analyses were conducted both with and without imputatedmissings. In all analyses the patterns were similar ${ }^{4}$.

\footnotetext{
${ }^{3} \mathrm{An}$ example of how the scores were corrected for observation time. Student X's time-on task in literacy activity = time observed: 50 minutes; time spent in literacy activity: 30 minutes; time on-task in literacy activity: 15 minutes $=(30 / 50)^{\star} 15=9$ minutes. Student 2 's time on-task in literacy activity $=$ time observed: 100 minutes; time spent in literacy activity: 30 minutes; time on-task in literacy activity: 15 minutes $=(30 / 100)^{\star} 15=4.5$ minutes.

${ }^{4}$ If desired the results can be retrieved from the first author.
} 


\subsection{Statistical Analyses}

Because the 63 students taking part in this study originally were selected from 10 different classes from 9 different schools ${ }^{5}$, we checked whether multi-level analyses were necessary by means of the program MLwiN (Rasbash et al., 2000). Results from the multi-level analyses showed that adding a class level to the student level did not result in a significant improvement of the model fit. Therefore, all analyses were carried outuni-level. First, means and standard deviations were computed for all variables for the whole sample. To examine the relationships with level of writing proficiency, correlations and effect sizes were computed for all engagement variables with average writing proficiency in grades 7 to 9. Students' development in writing proficiency was examined using GLM (General Linear Model) for repeated measures. Finally, for examining effects of engagement on development of writing proficiency, we used writing proficiency obtained in earlier grades (7 or 8 ) as covariates explaining writing proficiency in later grades( 8 or 9$)$. The effects of engagement on development were explored for each of the three time spans: grade 7 to 8 , grade 8 to 9 , and grade 7 to 9 . We did not use change scores to analyze development, since several studies have shown the regression approach to be superior (Allison, 1990; Pike, 2004; Senn, 2006; Tu, Gunnell, \& Gilthorpe, 2008).

\section{Results}

\subsection{Descriptive Results}

The means in Table 1 indicate that the students on average have quite some confidence in their literacy abilities and perceive literacy activities in school as quite useful. This is indicated by the average scores for self-efficacy and utility value, being close to 4 on the scale ranging from 1 (not at all) to 5 (very much). Furthermore, the means indicate that the students are neutral on average concerning their enjoyment of literacy activities: the mean for intrinsic value is just above the scale middle point (3). The means for perceived effort and perceived self-regulation indicate that students on average put some mental effort in literacy activities since both means are at (or very near to) the scale middle point. For perceived effort, this is defined by the two extremes: "not at all" and "very much". For self-regulation it is defined by the extremes: "sometimes" and "very frequently" (for executing specific strategies). With regard to students' behavioral engagement, the means indicate that more time on average was spend on literacy activities in language arts than in social studies. In addition, students were more on task in literacy activities in language arts on average (32.1 minutes) than in social studies (22.3 minutes). When time on task is divided by the time lessons were spend on literacy activities, the means show that students were on task $80 \%$ of the time in language arts and $75 \%$ of the time in social studies. The means for writing proficiency are based on the scaling procedure described in section 2.2.

${ }^{5}$ School and class level practically coincide in this study, since 10 classes come from 9different schools, so testing for a school level next to a class level is not feasible. 
Table 1. Means (standard deviations) of the study variables $(\mathrm{N}=63)$.

\begin{tabular}{lcc}
\hline & Scale & $M(S D)$ \\
\hline 1) Self-efficacy & $1-5$ & $3.85(.50)^{\mathrm{a}}$ \\
2) Intrinsic value & $1-5$ & $3.0(.72)^{\mathrm{a}}$ \\
3) Utilityvalue & $1-5$ & $3.94(.47)^{\mathrm{a}}$ \\
4) Perceived Effort & $1-5$ & $3.15(.68)^{\mathrm{a}}$ \\
5) PerceivedSelf-Regulation & $1-5$ & $3.0(.52)^{\mathrm{a}}$ \\
6) Language Arts & & \\
Time spent & - & $30.4(12.8)^{\mathrm{b}}$ \\
Time-on-task & - & $32.1(11.7)^{\mathrm{b}}$ \\
7) Social Studies & - & $29.6(15.5)^{\mathrm{b}}$ \\
Time spent & - & $22.3(10.4)^{\mathrm{b}}$ \\
Time-on-task & - & $234.7(96.1)$ \\
8) Writing proficiency grade 7 & - & $270.0(95.6)$ \\
9) Writing proficiency grade 8 & - & $294.3(68.9)$ \\
10) Writing proficiency grade 9 & & \\
\hline
\end{tabular}

aThese scales are calculated as the average of the average scores on the scales in each of the grades 7,8 and 9 . ${ }^{b}$ These means are the average of the average time observed in two lessons in each of the grades 7,8 and 9.

No absolute interpretation of their meaning is possible, since the scales werebased on the range of proficiency found in the sample. On the other hand, a comparison between the means in each grade indicates a steady progression in writing proficiency from grade 7 to grade 9 .

\subsection{Relations between Average Level of Writing Proficiency and Engagement}

To answer the first research question, Pearson correlations were computed between students' engagement and their average level of writing proficiency across grades 7 to $9(M=266.8, S D=73.2)$. Results show that writing proficiency is significantly predicted by intrinsic value $\left(r=.365, p<.025, r^{2}=.13\right)$ and timeon-task in social studies $\left(r=.302, p<.05, r^{2}=.09\right)$. The $r^{2}$ indicates that 13 percent of the variance is explained by intrinsic value and that 9 percent of the variance is explained by time-on-task in social studies. The low $r^{2}$ 's point to weak associations between these aspects of engagement and writing proficiency. Contrary to the expectations, results show no significant correlations for self-efficacy, utility value, perceived effort, perceived self-regulation and time-on-task in language arts with level of writing proficiency of low-achieving adolescents.

\subsection{Writing Development}

To answer the second research question, a repeated measures ANOVA was conducted with the scores for writing proficiency in grades $7-9$ as dependent variables. The results show that students significantly progressed in writing proficiency from grades 7 to $9\left(F_{(2,124)}=16.123, p<.001\right.$; partial $\left.\eta^{2}=.206\right)$. Within subject contrasts (repeated) show that the difference between grades 7 and 8 is 
significant $\left(F_{(1,62)}=16.60, p<.001 ;\right.$ partial $\left.\eta^{2}=.211\right)$. In addition, the difference between grade 8 and 9 is significant $\left(F_{(1,62)}=4.552, p<.05\right.$; partial $\left.\eta^{2}=.037\right)$. The effect sizes indicate that growth in writing proficiency is especially strong from grade 7 to 8 . But overall, students improved in writing proficiency in each grade. For that reason, we can conclude that there is a steady significant increase in writing proficiency for our group of low-achieving adolescents from grades 7 to 9.

\subsection{Relations between Development of Writing Proficiency and Engagement}

To answer the third research question, the associations of the engagement variables with development in writing proficiency were analyzed separately by means of linear regression for three time spans (grades $7-8,8-9$ and $7-9$ ). Writing proficiency scores in the earlier grades were entered first to control for students' initial writing proficiency. For all time spans, the results show that the writing proficiency in previous grades predicted writing proficiency in the later grades significantly $\left(7-8 r^{2}=.53, p<.001 ; 8-9 r^{2}=.23, p<.001 ; 7-9 r^{2}=.17, p\right.$ $<.001)$. Next, the engagement variables were entered into the regression separately to examine their contribution to the residual variance in writing proficiency. Results showed that none of the engagement variables had a significant contribution to the explanation of writing development. To illustrate the findings, Figure 1 shows the developmental patterns of students with higher and lower scores on two engagement variables based on a medium split. The left plot shows students with higher and lower intrinsic values and the right plot shows students with higher and lower perceived self-regulation. The developmental patterns show no clear differences in steepness of the developmental slopes, but rather signal that students who attribute more intrinsic value to literacy activities (left plot) are more proficient in writing and stay that way.
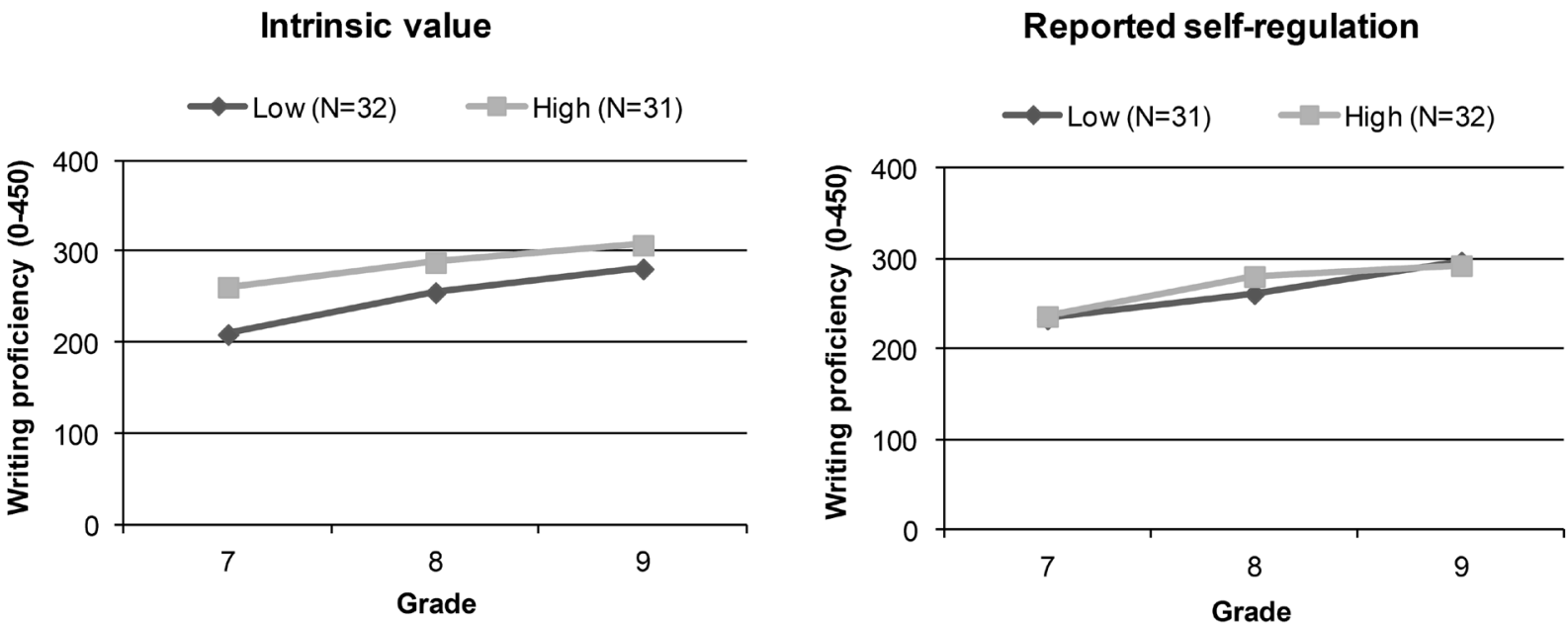

Figure 1. Writing development patterns to intrinsic value (left) and perceived self-regulation (right) for all students $(\mathrm{N}=63)$. 


\section{Discussion and Conclusions}

The main objective of this study was to make an important step in increasing our understanding of the roles of engagement as a predictor of the level and development of writing proficiency of low-achieving adolescents. To start with a positive message, the study showed that these low-achievers significantly improve their writing proficiency in the first three grades of secondary education (7-9). Contrary to pessimistic views about writing development of low-achievers (cf. Graham \& Perin, 2007; Inspectie van het Onderwijs, 2008; Salahu-Din, Persky \& Miller, 2008), these findings are encouraging in the light of the importance of writing proficiency for youngsters' academic, professional and societal careers.

Results of this study also show that intrinsic value as an indicator of affective engagement was positively associated with students' level of writing proficiency, while a relationship with development of writing proficiency between grades 7 9 was not evident. Our findings relating to the role of intrinsic value indicate that, although it may have contributed to writing development of low achieving adolescents in previous years of schooling, there is no additional effect of intrinsic value on development of writing proficiency in the following period (grades 7 - 9). Our findings suggest that students who developed a more positive attitude towards literacy activities (presumably at a younger age) are and remain the better writers in the same degree from the start of the study. It is not surprising that those who developed more negative attitudes towards writing and reading do not catch up, because such an effect would imply that negative attitudes are related to positive development. However, one could expect a continuation of the effect of positive intrinsic values for literacy practices, leading to a widening of the gap between better and poorer writers. The question is how to explain why such result is not found. Students who experience many difficulties with writing (such as most low-achieving adolescents) are likely to develop negative attitudes towards literacy activities at school (Archambault, Eccles, \& Vida, 2010). The development of these negative attitudes may be accompanied with a decrease in engagement in literacy activities generally found in adolescence and strongest for low-achieving students (Durik, Vida, \& Eccles, 2006; Eccles, Wigfield, \& Schiefele, 1998; Harter, Whitesell, \& Kowalski, 1992; Jacobs et al., 2002). This points to a possible explanation for not finding a relation between intrinsic values attached to literacy practices by low-achieving adolescents and their development of writing proficiency in 3 grades in a row. Even though some of them have more positive (or less negative!) attitudes at the start of secondary education (grade 7), this might be insufficient to motivate actual investment in literacy practices for accelerating their development of writing proficiency in the following period. Presumably, perceived intrinsic value is an important but not sufficient condition.

For utility value, no significant associations were found with the level and development of writing proficiency. These findings may suggest that low achieving adolescents' perceptions of the usefulness of literacy skills are independent of 
their writing proficiency. Students in our study were quite convinced of the importance of writing for their current and future goals; they scored around 4 on average on a scale ranging from 1 to 5 . It is possible that students who report that writing is highly useful primarily refer to writing for future use. In that case, they would not feel the need to develop skills directed to better writing at school. They might therefore be more focused on getting the job done than on writing texts of good quality. In that case, higher perceived utility of writing would not lead to more successful development of writing proficiency; neither would it be related to a higher level of writing proficiency. Instead, frequent practice with effortful and strategic approaches is what adolescents need in order to enhance their writing proficiency (Graham \& Perin, 2007; Harris et al., 2009). Furthermore, perceived utility of literacy activities (such as "writing is important") is a quite distant motive for writing for low-achieving adolescents and can become easily overruled by more direct and personal reasons for not enacting in literacy activities (such as "writing is boring" or "it is more fun to play games") (Van Kruistum, Leseman, \& De Haan, 2013). Future research should provide more insight into the role of these "undermining" motivations for low-achieving adolescents to engage in writing, such as task avoidance, competitive activities and perceived task difficulty.

Contrary to what theories on self-efficacy presume (Bandura, 1997; Klassen, 2002; Pajares, 2003; Pajares \& Valiante, 2006), no indications were found for the impact of self-efficacy on both level and development of writing proficiency of low-achieving adolescents. The fact that self-efficacy does not seem to be a predictor of writing development among low-achieving adolescents must be related to the high self-efficacy scores found in our sample; around 4 on a scale ranging from 1 to 5. High self-efficacy beliefs are often found for low-achieving students (Klassen, 2002; Harris \& Graham, 1992). These high beliefs can be regarded as a coping strategy of low-achievers to persist in the face of difficulties. High selfefficacy beliefs are also likely to be fostered by the learning environment. The low-achieving adolescents in our study are enrolled in a tracked school system in secondary education. As a consequence, these students are surrounded by a comparison group with low academic and literacy skills. Moreover, the difficulty of literacy tasks is adapted to their abilities and their teachers are inclined to boost students' confidence. In such a learning environment, low-achieving adolescents may perceive themselves as quite competent in writing despite the fact that their writing skills are poor compared with other students. Consequently, these students' self-efficacy beliefs may not match their actual performance. At high levels of self-efficacy, students even may feel overconfident resulting in failure to allocate resources and effort and therefore may retard instead of boost learning (Salomon, 1984; Sawyer, Graham, \& Harris, 1992). This may explain why low-achieving adolescents with high self-efficacy beliefs do not seem to be more proficient writers than their classmates and do not develop better writing skills in the three grades of schooling studied either.

We also examined the impact of cognitive engagement on the level and de- 
velopment of writing proficiency. For both perceived effort and perceived self-regulation no significant relationships were found. Given the strong body of research demonstrating positive links between self-regulation and writing proficiency (Graham, 2006), these findings were unexpected. One explanation may be that low-achieving adolescents experience much difficulty with self-regulatory aspects of literacy practices (Bereiter \& Scardamalia, 1987; De Milliano et al., 2012; Englert et al., 1988). Therefore, more self-regulation and cognitive effort may not necessarily be related to better writing proficiency norto more progression over the three grades studied. The expenditure of more cognitive effort and self-regulation does only result in better level and development of writing proficiency, when this effort is based on valuable knowledge about writing strategies, personal strengths and weaknesses, and criteria for good writing, knowledge that our low-achieving adolescents probably do not possess in a sufficient amount. In addition, efficient cognitive effort and self-regulation are task- and situationspecific. Dependent on the topics and goals of particular tasks, prior knowledge needed for executing, motivation to succeed and linguistic and regulative skills, writers may apply more or less successful self-regulation (Zimmerman \& Schunk, 1989). These complicating factors may explain why self-reports of students' effort and self-regulation directed to literacy activities in a much more general sense, as used in the present study, are not related to level or development of writing proficiency of the students. Finally, using self-reports as indications of cognitive engagement may have an important disadvantage. Respondents do not always do what they say they do in such general retrospective selfreports (Cromley \& Azevedo, 2006; Veenman, Van Hout-Wolters, \& Afflerbach, 2006). Research into the relations between actual self-regulatory behavior and writing quality of specific tasks, for example using think-aloud procedures, is therefore needed to corroborate our findings. Interestingly, a study of De Milliano et al. (2012) demonstrated that such an approach reveals that positive relationships do exist between sequential patterns of self-regulatory activities undertaken by low-achieving adolescents and their writing quality.

In regard to behavioral engagement, a significant positive relationship was found between level of writing proficiency and time-on-task in literacy activities in social studies lessons, but not with time-on-task in language arts lessons. These findings are consistent with the idea that effects of engagement are sensitive to variation in learning contexts (Appleton et al., 2008; Finn \& Rock, 1997; Fredricks et al., 2004; Guthrie et al., 2012; Linnenbrink \& Pintrich, 2003). Nevertheless, the difference found between the effects of engagement between the two learning contexts is striking and requires an explanation. First, we have to emphasize that the effect found for engagement in social studies is on the level of writing proficiency and not on development in writing proficiency over the three grades studied. Therefore, we can exclude that the association points to a causal relation between writing proficiency and the nature of the literacy activities in the two types of lessons (literacy skill oriented in language arts vs. content oriented in social studies). In other words, if the relations were causal, we would 
expect that students being more engaged in literacy activities in social studies, would not per se be the ones with better writing proficiency, but would be the ones that grew more in writing proficiency across the grades $7-9$. The results do indicate, however, that better writers are more engaged in social studies than poorer writers. A provisional explanation for this finding may be that literacy practices that are instrumental for obtaining knowledge about subject contents in the social studies may be more challenging and engaging for better writers than for the poorer writers in our classrooms, resulting in more time on task on such practices of the former group. This explanation points to the premises of content-oriented language learning as proposed by the approaches of Content-Based Language Learning (Brinton, Snow, \& Wesche, 2003; Bygate, Skehan, \& Swain, 2001) and Concept-Oriented Reading Instruction (Guthrie \& Wigfield, 2000; Guthrie et al., 2004), emphasizing instrumental literacy experience over skill oriented literacy instruction, which is mostly the normal object of language arts lessons. However, our finding does not directly support the claim that this approach supports writing development, given the absence of indications for a causal role. Future research into the role of engagement in literacy in contentarea education is certainly needed to validate our findings and explanation.

The question remains why we were not able to detect associations between students' behavioral engagement in the classroom and development of their writing proficiency in the three grades studied. Students participating more in the learning opportunities offered, are generally expected to benefit more from education (Pressley et al., 2001; Greenwood et al., 2002). Therefore, not finding relations between behavioral engagement in literacy activities and development of writing proficiency is quite disappointing. It suggests that for the low-achieving students in our study it did not matter how much they were engaged in literacy activities in language arts and social studies. Their on-task behavior did not affect their writing development in a significant way. However, behavioral engagement at school is not only a matter of quantity but also of the nature of students' behavior and the quality of the learning environment. Although time-ontask behavior does inform us about the amount of behavioral engagement, it does not tell us much about the quality of students' literacy activities. Nor does time-on-task behavior provide good indications of the quality of the learning environment that students were engaged in. The nature and setting of literacy activities and behavior of teachers determine to what extent students benefit from instruction (Brekelmans, Sleegers, \& Fraser, 2000; Furrer \& Skinner, 2003; Guthrie et al., 2012). Future research into behavioral engagement should therefore not only look at time-on-task behavior, but also focus on the nature of students' behavioral engagement in relation to the nature of the learning environments.

This study suggests that the role of engagement for writing proficiency seems to be different for low-achieving adolescents compared to what is known from earlier studies directed at more heterogeneous and younger writers. Our findings, therefore, show the value of research directed at a focused sample of low- 
achieving adolescents in particular. In addition, the results show that different dimensions of engagement (cognitive, affective and behavioral) may have different roles in determining students writing proficiency. More importantly, however, the findings underline the importance of distinguishing between level and development of writing proficiency in examining relationships between engagement and writing achievement. This study has shown that significant relationships between level of writing proficiency and engagement were not accompanied by significant relationships between engagement and development of writing proficiency during a three year period. This finding calls for caution in interpreting correlations between proficiency and engagement in terms of consequences for students' future writing development. Correlations between level of writing proficiency and engagement (specifically intrinsic value and behavioral engagement) do not necessarily indicate that more engagement has beneficial effects on writing proficiency. It may also indicate that better writers are more engaged than poorer writers, because of them experiencing less difficulty in writing. Alternatively, a correlation may also point to previous experiences with writing in education that resulted in better writing, while this effect does not continue in the present period of adolescence studied (grades 7 - 9). Such correlations may indicate why some writers are more proficient than others, but they do not necessarily predict development of writing proficiency in the studied period of adolescence. Although we found that on average all our low-achieving adolescents improved in writing proficiency in this period, there are serious questions to be asked about the quality of the learning environments at their schools, given that none of the engagement variables studied seem to make a difference for writing development. We therefore call for more longitudinal studies into writing proficiency of low-achieving students covering the different dimensions of engagement and focusing on factors that do seem to matter not only for explaining general level of writing proficiency but also for development in a certain period of schooling.

While we believe that this study makes a unique contribution to the field of writing engagement, we also acknowledge its limitations. First, the small sample size calls for caution. Given this small sample we were able to find only sizeable effects of engagement. We therefore cannot exclude that with a larger sample relatively small effects will be found. In addition, we recognize that our findings are not based on a representative national sample of low-achieving adolescents and therefore cannot account for all the differences that might exist between their learning contexts (let alone international educational systems). Replication of this study using other samples of low-achieving adolescents is needed to validate our findings. Furthermore, research is needed into other indicators of engagement, such as perceived autonomy (Guthrie et al., 2007), mastery and performance goals, (Meece \& Miller, 2001; Pintrich, 2000), undermining motivations (Guthrie et al., 2009) and social motivations (Furrer \& Skinner, 2003; Guthrie et al., 2007). These facets of engagement may as well contribute to lowachieving adolescents' writing proficiency. Finally, the relationship between en- 
gagement and competence may be reciprocal (Morgan \& Fuchs, 2007). The design and analysis used in our study did not capture such reciprocal effects. They could be unraveled by experimental research designs in which engagement is optimized. Still, we believe that this explorative longitudinal study has made an important contribution to increasing our understanding of low-achieving adolescents' writing development and the roles of affective, cognitive and behavioral engagement and has offered some important points of departure for future research on this significant topic.

\section{Acknowledgements}

This research was funded by the Dutch Organisation of Scientific Research NWO-PROO. The authors are thankful to the members of project SALSA for their useful comments.

\section{References}

Alliance for Excellent Education (2006). 2006 Alliance Annual Report. Seattle: Alliance for Excellent Education.

Allison, P. D. (1990). Change Scores as Dependent Variables in Regression Analysis. Sociological Methodology, 20, 93-144. https://doi.org/10.2307/271083

Applebee, A., \& Langer, J. (2006). The State of Writing Instruction in America's Schools: What Existing Data Tell Us. Albany, NY: Center on English Learning and Achievement.

Appleton, J. J., Christenson, S. L., \& Furlong, M. J. (2008). Student Engagement with School: Critical Conceptual and Methodological Issues of the Construct. Psychology in the Schools, 45, 369-386. https://doi.org/10.1002/pits.20303

Archambault, I., Eccles, J. S. \& Vida, M. N. (2010). Ability Self-Concepts and Subjective Value in Literacy. Joint Trajectories from Grades 1 Through 12. Journal of Educational Psychology, 102, 804-816. https://doi.org/10.1037/a0021075

Baker, L., \& Brown, A. L. (1984). Meta-Cognitive Skills and Reading. In P. D. Pearson (Ed.), Handbook of Reading Research (Vol. 1, pp. 353-394). New York, NY: Longman.

Bandura, A. (1997). Self-Efficacy: The Exercise of Control. New York, NY: Freeman.

Baumert, J., Klieme, E., Neubrand, M., Prenzel, M., Schiefele, U., Schneider, W., Stanat, P., Tillmann, K.-J., \& Weiß, M. (2001). PISA 2000. Basiskompetenzen von Schülerinnen und Schülern im internationalen Vergleich.

Bereiter, C., \& Scardamalia, M. (1987). The Psychology of Written Composition. Hillsdale, NJ: Lawrence Erlbaum Associates.

Berliner, D. C. (1979). Tempus Educare. In P. L. Peterson, \& H. J. Walberg (Eds.), Research on Teaching: Concepts, Findings and Implications (pp. 120-136). Richmond, CA: Mc Cutchan Publishing Corporation.

Blok, H. (1986). Essay Rating by the Comparison Method. Journal for Educational Research, 11, 169-176.

Boscolo, P. (2012). Teacher-Based Writing Research. In V. M. Berninger (Ed.), Past, Present, and Future Contributions of Cognitive Writing Research to Cognitive Psychology (pp. 61-86). London: Psychology Press.

Brekelmans, M., Sleegers, P., \& Fraser, B. J. (2000). Teaching for Active Learning. In P. R. J. Simons, J. L. van der Linden, \& T. Duffy (Eds.), New Learning (pp. 227-242). Dor- 
drecht: Kluwer Academic Publishers. https://doi.org/10.1007/0-306-47614-2_12

Brinton, D. M, Snow, M. A., \& Wesche, M. (2003). Content-Based Second Language Instruction (2nd ed.). Ann Arbor: University of Michigan Press. https://doi.org/10.3998/mpub.8754

Bruning, R., \& Horn, C. (2000). Developing Motivation to Write. Educational Psychologist, 35, 25-37. https://doi.org/10.1207/S15326985EP3501_4

Bygate, M., Skehan, P., \& Swain, M. (2001). Introduction. In M. Bygate, P. Skehan, \& M. Swain (Eds.), Researching Pedagogic Tasks: Second Language Learning, Teaching and Testing (pp. 1-20). New York: Pearson Education Limited.

Cromley, J. G., \& Azevedo, R. (2006). Self-Report of Reading Comprehension Strategies: what Are We Measuring? Metacognition Learning, 1, 229-247.

https://doi.org/10.1007/s11409-006-9002-5

De La Paz, S., Swanson, P. N., \& Graham, S. (1998). The Contribution of Executive Control to the Revising of Students with Writing and Learning Difficulties. Journal of Educational Psychology, 90, 448-460. https://doi.org/10.1037/0022-0663.90.3.448

De Milliano, I., Van Gelderen, A., \& Sleegers, P. (2012). Patterns of cognitive self-regulation of adolescent struggling writers. Written Communication, 29, 303-325.

https://doi.org/10.1177/0741088312450275

Dolezal, S. E., Welsh, L. M., Pressley, M., \& Vincent, M. M. (2003). How Nine Third-Grade Teachers Motivate Student Academic Engagement. The Elementary School Journal, 103, 239-267. https://doi.org/10.1086/499725

Durik, A. M., Vida, M., \& Eccles, J. S. (2006). Task Values and Ability Beliefs as Predictors of High School Literacy Choices: A Developmental Analysis. Journal of Educational Psychology, 98, 382-393. https://doi.org/10.1037/0022-0663.98.2.382

Eccles, J. S. (2005). Subjective Task Value and the Eccles et al. Model of Achievement-Related Choices. In A. J. Elliot, \& C. S. Dweck (Eds.), Handbook of Competence and Motivation (pp. 105-121). New York, NY: The Guilford Press.

Eccles, J. S., \& Wigfield, A. (2002). Motivational Beliefs, Values, and Goals. Annual Review of Psychology, 53, 109-132. https://doi.org/10.1146/annurev.psych.53.100901.135153

Eccles, J. S., Wigfield, A., \& Schiefele, U. (1998). Motivation to Succeed. In N. Eisenberg (Ed.), Handbook of Child Psychology, Volume 3 Social, Emotional, and Personality Development (5th ed.). New York, NY: Wiley.

Englert, C. S. (1992). Writing Instruction from a Sociocultural Perspective: The Holistic, Dialogic, and Social Enterprise of Writing. Journal of Learning Disabilities, 25, 153 172. https://doi.org/10.1177/002221949202500303

Englert, C. S., Raphael, T. H. E., Fear, K. L., \& Anderson, L. M. (1988). Students' Meta-Cognitive Knowledge about How to Write Informal Texts. Learning Disability Quarterly, 11, 18-46. https://doi.org/10.2307/1511035

Finn, J. D., \& Rock, D. A. (1997). Academic Success among Students at Risk for School Failure. Journal of Applied Psychology, 82, 221-234. https://doi.org/10.1037/0021-9010.82.2.221

Fredricks, J. A., Blumenfeld, P. C., \& Paris, A. H. (2004). School Engagement: Potential of the Concept, State of Evidence. Review of Educational Research, 74, 59-109. https://doi.org/10.3102/00346543074001059

Furrer, C., \& Skinner, E. (2003). Sense of Relatedness as a Factor in Children's Academic Engagement and Performance. Journal of Educational Psychology, 95, 148-162. https://doi.org/10.1037/0022-0663.95.1.148 
Graham, S. (2006). Writing. In P. Alexander, \& P. Winne (Eds.), Handbook of Educational Psychology (pp. 457-478). Mahwah, NJ: Erlbaum.

Graham, S., \& Harris, K. R. (2012). The Role of Strategies, Knowledge, Will, and Skills in a 30 Year Program of Research (with Homage to Hayes, Fayol, and Boscolo). In V. M. Berninger (Ed.), Past, Present, and Future Contributions of Cognitive Writing Research to Cognitive Psychology (pp. 177-196). London: Psychology Press.

Graham, S., \&Perin, D. (2007). Writing Next. Effective Strategies to Improve Writing of Adolescents in Middle and High Schools. New York, NY: Alliance for Excellent Education.

Graham, S., Berninger, V., \& Fan, W. (2007). The Structural Relationship between Writing Attitude and Writing Achievement in First and Third Grade Students. Contemporary Educational Psychology, 32, 516-536.

Greenwood, C. R., Horton, B. T., \& Utley, C. A. (2002). Academic Engagement: Current Perspectives on Research and Practice. School Psychology Review, 31, 328-349.

Guthrie, J. T., \& Wigfield, A. (2000). Engagement and Motivation in Reading. In M. L. Kamil, P. B. Mosenthal, P. D. Pearson, \& R. Barr (Eds.), Handbook of Reading Research (3rd Ed.). New York, NY: Longman.

Guthrie, J. T., Coddington, C. S., \& Wigfield, A. (2009). Profiles of Motivation for Reading among African American and Caucasian students. Journal of Literacy Research, 41, 317-353. https://doi.org/10.1080/10862960903129196

Guthrie, J. T., McRae, A., \& Klauda, S. L. (2007). Contributions of Concept-Oriented Reading Instruction to knowledge about Interventions for Motivations in Reading. Educational Psychologist, 42, 237-250. https://doi.org/10.1080/00461520701621087

Guthrie, J. T., Wigfield, A., \& You, W. (2012). Instructional Contexts for Engagement and Achievement in Reading. In S. Christensen, A. Reschly, \& C. Wylie (Eds.), Handbook of Research on Student Engagement (pp. 601-634). New York, NY: Springer Science. https://doi.org/10.1007/978-1-4614-2018-7_29

Guthrie, J. T., Wigfield, A., Barbosa, P., Perencevich, K. C., Taboada, A., Davis, M. H. et al. (2004). Increasing Reading Comprehension and Engagement through ConceptOriented Reading Instruction. Journal of Educational Psychology, 96, 403-423. https://doi.org/10.1037/0022-0663.96.3.403

Harris, K. R., \& Graham, S. (1992). Helping Young Writers Master the Craft: Strategy Instruction and Self-Regulation in the Writing Process. Cambridge, MA: Brookline Books.

Harris, K. R., Graham, S., Brindle, M., \& Sandmel, K. (2009). Metacognition and Children's Writing. In R. J. Sternberg, D. J. Hacker, J. Dunlosky, \& A. C. Graesser (Eds.), Handbook of Metacognition in Education (pp. 131-153). New York, NY: Lawrence Erlbaum and Associates.

Harter, S., Whitesell, N. R., \& Kowalski, P. (1992). Individual Differences in the Effects of Educational Transitions on Young Adolescents' Perceptions of Competence and Motivational Orientation. American Educational Research Journal, 29, 777-808.

https://doi.org/10.3102/00028312029004777

Hayes J. R., \& Flower, L. S. (1980). Identifying the Organization of Writing Processes. In L. W. Gregg, \& E. R. Steinberg (Eds.), Cognitive Processes in Writing (pp. 3-30). Hillsdale, NJ: Erlbaum.

Hayes, J. R. (1996). A New Framework for Understanding Cognition and Affect in Writing. In C. M. Levy, \& S. Ransdell (Eds.), The Science of Writing: Theories, Methods, Individual Differences and Applications (pp. 1-27). Mahwah, NJ: Erlbaum.

Hidi, S., \& Boscolo, P. (2006). Motivation and Writing. In C. A. MacArthur, S. Graham, 
\& J. Fitzgerald (Eds.), Handbook of Writing Research (pp. 144-157). New York: The Guilford Press.

Hofman, R. H., Spijkerboer, A. W., \& Timmermans, A. C. (2009). Ervaren deficiënties door havo en mbo-opleidingen in de basisbagage van vmbo'ers. Studie uitgevoerd door Gronings Instituut voor Onderzoek van Onderwijs in opdracht van de Onderwijsraad. Den Haag: Onderwijsraad.

Hughes, J., \& Kwok, O. (2007). Influence of Student-Teacher and Parent-Teacher Relationships on Lower Achieving Readers' Engagement and Achievement in the Primary Grades. Journal of EducationalPsychology, 99, 39-51.

https://doi.org/10.1037/0022-0663.99.1.39

Inspectie van het onderwijs (2008). Basisvaardigheden taal in het voortgezet onderwijs. Resultaten van een inspectieonderzoek naar taalvaardigheid in de onderbouw van het vmbo en praktijkonderwijs. Utrecht: Inspectie van het Onderwijs.

Jacobs, J. E., Lanza, S., Osgood, D., Eccles, J. S., \& Wigfield, A. (2002). Changes in Children's Self-Competence and Values: Gender and Domain Differences across Grades One through Twelve. Child Development, 73, 509-527.

https://doi.org/10.1111/1467-8624.00421

Kellogg, R. T. (1987). Effects of Topic Knowledge on the Allocation of Processing Time and Cognitive Effort to the Writing Processes. Memory and Cognition, 15, 256-266. https://doi.org/10.3758/BF03197724

Kiuhara, S. A., Graham, S., \& Hawken, L. S. (2009). Teaching Writing to High School Students: A National Survey. Journal of Educational Psychology, 101, 136-160. https://doi.org/10.1037/a0013097

Klassen, R. (2002). Writing in Early Adolescence: A Review of the Role of Self-Efficacy Beliefs. Educational Psychology Review, 14, 173-203. https://doi.org/10.1023/A:1014626805572

Ladd, G. W., \& Dinella, L. M. (2009). Continuity and Change in Early School Engagement: Predictive of Children's Achievement Trajectories from First to Eighth Grade? Journal of Educational Psychology, 101, 190-206. https://doi.org/10.1037/a0013153

Linnenbrink, E. A., \& Pintrich, P. R. (2003). The Role of Self-Efficacy Beliefs in Student Engagement and Learning in the Classroom. Reading and Writing Quarterly, 19, 119-137. https://doi.org/10.1080/10573560308223

Lipstein, R., \& Renninger, K. A. (2007). "Putting Things into Words": The Development of 12-15-Year-Old Students' Interest for Writing. In P. Boscolo, \& S. Hidi (Eds.), Motivation and Writing: Research and School Practice (pp. 113-140). New York, NY: Elsevier.

Lloyd-Jones, R. (1977). Primary Trait Scoring. In C. R. Cooper, \& L. Odell (Eds.), Evaluating Writing: Describing, Measuring, Judging (pp. 33-66). Urbana, IL: National Council of Teachers of English.

McCutchen, D. (1986). Domain Knowledge and Linguistic Knowledge in the Development of Writing Ability. Journal of Memory and Language, 25, 431-444.

Meece, J. L., \& Miller, S. D. (2001). Longitudinal Analysis of Elementary School Students' Achievement Goals in Literacy Activities. Contemporary Educational Psychology, 26, 454-480. https://doi.org/10.1006/ceps.2000.1071

Morgan P. L., \& Fuchs, D. (2007). Is There a Bidirectional Relationship between Children's Reading Skills and Reading Motivation? Council for Exceptional Children, 73, 165-183. https://doi.org/10.1177/001440290707300203

OECD (2000). Literacy in the Information Age. Final Report of the International Adult 
Literacy Survey.

Olinghouse, N. G., \& Graham, S. (2009). The Relationship between the Writing Knowledge and the Writing Performance of Elementary-Grade Students. Journal of Educational Psychology, 101, 37-50. https://doi.org/10.1037/a0013462

Pajares, F. (2003). Self-Efficacy Beliefs, Motivation, and Achievement in Writing: A Review of the Literature. Reading and Writing Quarterly, 19, 139-158.

https://doi.org/10.1080/10573560308222

Pajares, F., \& Valiante, G. (2006). Self-Efficacy Beliefs and Motivation in Writing Development. In C. MacArthur, S. Graham, \& J. Fitzgerald (Eds.), Handbook of Writing Research (pp. 158-170). New York, NY: Guilford Press.

Pike, G. R. (2004). Lord's Paradox and the Assessment of Change during College. Journal of College Student Development, 45, 348-353. https://doi.org/10.1353/csd.2004.0040

Pintrich, P. R. (2000). The Role of Goal Orientation in Self-Regulated Learning. In M. Boekaerts, P. R. Pintrich, \& M. Zeidner (Eds.), Handbook of Self-Regulation: Theory, Research, and Applications (pp. 451-502). San Diego, CA: Academic Press.

Ponitz, C. C., McClelland, M. M., Matthews, J. M., \& Morrison, F. J. (2009). A Structured Observation of Behavioral Self-Regulation and Its Contribution to Kindergarten Outcomes. Developmental Psychology, 45, 605-619. https://doi.org/10.1037/a0015365

Ponitz, C. C., Rimm-Kaufman, S. E., Grimm, K. J., \& Curby, T. W. (2009). How Kindergarten Classroom Quality Contributes to Reading Achievement: The Critical Role of Behavioral Engagement. School Psychology Review, 38, 102-120.

Pressley, M., \&Afflerbach, P. (1995). Verbal Protocols of Reading: The Nature of Constructively Responsive Reading. Hillsdale, NJ: Erlbaum.

Pressley, M., Wharton-McDonald, R., Allington, R., Block, C. C., Morrow, L., Tracey, D. et al. (2001). A Study of Effective Grade-1 Literacy Instruction. Scientific Studies of Reading, 5, 35-58. https://doi.org/10.1207/S1532799XSSR0501_2

Rasbash, J., Browne, W. J., Goldstein, H., Yang, M., Plewis, I., Healy, M., Woodhouse, G., Draper, D., Langford, I., \& Lewis, T. (2000). A User's Guide to MLwiN(2nd ed.). London: Institute of Education.

Salahu-Din, D., Persky, H., \& Miller, J. (2008). The Nation's Report Card: Writing 2007: National Assessment of Educational Progress (NAEP).

Salomon, G. (1984). Television Is "Easy" and Print Is “Tough": The Differential Investment of Mental Effort in Learning as a Function of Perceptions and Attributions. Journal of Educational Psychology, 76, 647-658. https://doi.org/10.1037/0022-0663.76.4.647

Sawyer, R. J., Graham, S., \& Harris, K. R. (1992). Direct Teaching, Strategy Instruction, and Strategy Instruction with Explicit Self-Regulation: Effects on the Composition Skills and Self-Efficacy of Students with Learning Disabilities. Journal of Educational Psychology, 84, 340-352. https://doi.org/10.1037/0022-0663.84.3.340

Schoonen, R., Van Gelderen, A., Stoel, R., Hulstijn, J., \& De Glopper, K. (2011). Modeling the Development of L1 and EFL Writing Proficiency of Secondary-School Students. Language Learning, 6, 31-79. https://doi.org/10.1111/j.1467-9922.2010.00590.x

Schunk, D. H., \& Zimmerman, B. J. (1994). Self-Regulation of Learning and Performance: Issues and Educational Applications. Hillsdale, NJ: Erlbaum.

Senn, S. (2006). Change from Baseline and Analyses of Covariance Revisited. Statistics in Medicine, 25, 4334-4344. https://doi.org/10.1002/sim.2682 
Torrance, M., Fidalgo, R., \& Garcia, J. N. (2007). The Teachability and Effectiveness of Cognitive Self-Regulation in Sixth-Grade Writers. Learning and Instruction, 17, 265285.

Tu, Y.-K., Gunnell, D., \& Gilthorpe, M. S. (2008). Simpson's Paradox, Lord's Paradox, and Suppression Effects are the Same Phenomenon-The Reversal Paradox. Emerging Themes in Epidemiology, 5, 2. https://doi.org/10.1186/1742-7622-5-2

Van Gelderen, A. (1997). Elementary Students' Skills in Revising; Integrating Quantitative and Qualitative Analysis. Written Communication, 14, 360-397. https://doi.org/10.1177/0741088397014003003

Van Kruistum, C. J. (2013). Changing Engagement of Youth in Old and New Media Literacy. Patterns, Functions and Meanings. Doctoral Dissertation, Utrecht: Utrecht University.

Veenman, M. V. J., Van Hout-Wolters, B. H. A. M., \& Afflerbach, P. (2006). Meta-Cognition Learning: Conceptual and Methodological Considerations. Meta-Cognition and Learning, 1, 3-14. https://doi.org/10.1007/s11409-006-6893-0

Wigfield, A., \& Eccles, J. S. (2000). Expectancy-Value Theory of Achievement Motivation. Contemporary Educational Psychology, 25, 68-81. https://doi.org/10.1006/ceps.1999.1015

Zimmerman, B. J., \& Schunk, D. H. (1989). Self-Regulated Learning and Academic Achievement: Theory, Research and Practice. New York, NY: Springer-Verlag. https://doi.org/10.1007/978-1-4612-3618-4

Zimmerman, J. B., \& Risemberg, R. (1997). Becoming a Self-Regulated Writer: A Social Cognitive Perspective. Contemporary Educational Psychology, 22, 73-101. https://doi.org/10.1006/ceps.1997.0919

Submit or recommend next manuscript to SCIRP and we will provide best service for you:

Accepting pre-submission inquiries through Email, Facebook, LinkedIn, Twitter, etc. A wide selection of journals (inclusive of 9 subjects, more than 200 journals)

Providing 24-hour high-quality service

User-friendly online submission system

Fair and swift peer-review system

Efficient typesetting and proofreading procedure

Display of the result of downloads and visits, as well as the number of cited articles

Maximum dissemination of your research work

Submit your manuscript at: http://papersubmission.scirp.org/

Or contact ce@scirp.org 